\section{DIARY}

\section{$\mathrm{MARCH}$}

UCL Eastman Dental Institute

CPD Conference

Date: 19 March 2010

Venue: London

www.eastman.ucl.ac.uk

The Dentistry Show

Date: 19-20 March 2010

Venue: NEC Birmingham

www.thedentistryshow.co.uk

BDA clinical expert series:

Innovations in aesthetic dentistry

Date: 26 March 2010

Venue: London

\section{APRIL}

BDA Seminar - Growing your practice in challenging times

Date: 23 April 2010

Venue: Leeds Marriott Hotel, Leeds

HC2010 health informatics conference and exhibition

Date: 27-29 April 2010

Venue: International Conference

Centre (ICC), Birmingham

www.hc2010.co.uk

\section{MAY}

British Dental Conference

and Exhibition 2010

Date: 20-22 May 2010

Venue: Arena and Convention Centre,

Liverpool

Tel: 08701666625

Email:bda@delegate.com

www.bda.org

\section{JUNE}

Annual Meeting of the European Society of Dental Ergonomics

Date: 4-5 June 2010

Venue: Ghent University Hospital,

Ghent, Belgium

Email: secretary-general@esde.org

www.esde.org

BDA Seminar - Introduction to

being an associate

Date: 25 June 2010

Venue: London

www.bda.org

\section{DENTURE ADHESIVE PRODUCT WARNING ISSUED}

GlaxoSmithKline (GSK) has issued a consumer advisory warning about a potential health risk associated with long-term, excessive use of GSK's zinccontaining denture adhesives Poligrip Ultra and Poligrip Total Care.

As a precautionary measure GSK has voluntarily stopped the manufacture, distribution and advertising of these products. The move has followed reports of adverse events which, together with published literature, suggested that excessive use of these products, typically for several years, may lead to the development of high levels of zinc in the body, which are associated with neurological symptoms such as numbness, tingling or weakness in the arms and legs, difficulties with walking and balance and blood problems such as anaemia.

The company says that Poligrip Ultra and Poligrip Total Care are safe to use as directed on the product label, which the majority of consumers follow. However, some consumers apply more adhesive than directed and use it more than once per day.

GSK has issued consumer advice in which it instructs consumers who have been using the product correctly that
GlaxoSmithKline Consumer Healthcare

they may continue to do so safely, but must ensure they are using the products as directed on the package.

For those who have been using Poligrip Ultra and Poligrip Total Care for several years in greater amounts than directed on the package, for example using adhesive more than once per day or using up adhesive in a shorter time than directed on the label (a typical 40g tube should last about 6 weeks), or those who have concerns about their health, GSK is advising patients to stop using the product, talk to their doctor and use a zinc-free alternative adhesive.

The company adds that if dentists have any patients who describe neurological symptoms associated with longterm excessive denture adhesive use, they should refer the patient to their GP for assessment and ask that dentists report the case to GSK at 0208047 2500. Any other consumer queries can be directed to its consumer call line at 0800988 6366. The return of Poligrip samples should be arranged via your GSK representative.

\title{
DENTAL EXECUTIVE APPOINTED
}

Professor Damien Walmsley, Professor of Restorative Dentistry at the University of Birmingham School of Dentistry and Scientific Advisor to the BDA and $B D J$, has been elected as the dental representative to the executive committee of the Health Sciences network of Universitas 21 (www.u21health.org).

This network was established to provide Faculty within U21 member universities with a framework for exploring opportunities for collaborative research, student centred initiatives, information exchange, and sharing of resources.

The section has met on a regular basis since 2001. Within health sciences there are nine dental schools involved, the Universities of Birmingham, British Columbia, Hong Kong, Korea, McGill,
Melbourne, Queensland, Monterrey, and Singapore. Noteworthy projects include a student International Peer Review in blog format, e-learning projects including forensic odontology, benchmarking between schools and trans-cultural communication training.

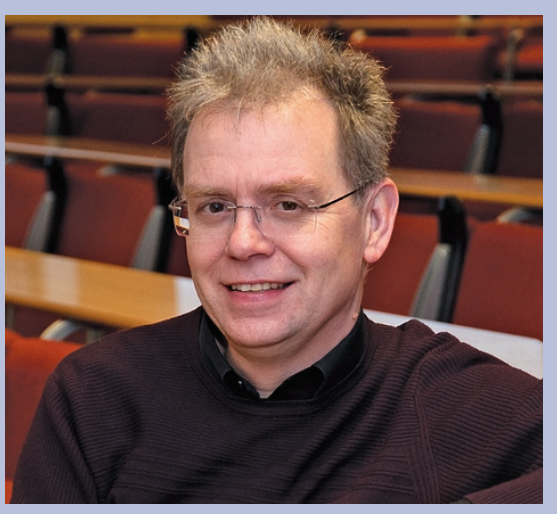

